\section{Overexposure of radiation therapy patients in Panama: problem recognition and follow-up measures}

\section{Cari Borrás ${ }^{1}$}

Suggested citation: Borrás C. Overexposure of radiation therapy patients in Panama: problem recognition and follow-up measures. Rev Panam Salud Publica. 2006;20(2/3);173-87.

Key words: pelvic neoplasms, radiotherapy, radiation injuries, quality control, Panama.

\footnotetext{
Pan American Health Organization, Washington, D.C., United States of America. Send correspondence to: Dr. Cari Borrás, 150144 th Street, N.W., Washington, D.C. 20007, United States; e-mail: cariborras@ starpower.net.
}

\section{SYNOPSIS}

This report summarizes and analyzes the responses of various organizations that provided assistance to the National Oncology Institute (Instituto Oncológico Nacional, ION) of Panama following the overexposure of 28 radiation therapy patients at the ION in late 2000 and early 2001. The report also looks at the long-term measures that were adopted at the ION in response to the overexposure incident, as well as implications that the incident has for other cancer treatment centers worldwide. In March 2001, the director of the ION was notified of serious overreactions in patients undergoing radiation therapy for cancer treatment. Of the $478 \mathrm{pa}$ tients treated for pelvic cancers between August 2000 and March 2001, 3 of them had died, possibly from an overdose of radiation. In response, the Government of Panama invited international experts to carry out a full investigation of the situation. Medical physicists from the Pan American Health Organization (PAHO) were among those invited. They ascertained that 56 patients treated with partially blocked teletherapy fields for cancers of the uterine cervix, endometrium, prostate, or rectum, had had their treatment times calculated using a computerized treatment planning system. PAHO's medical physicists calculated the absorbed doses received by the patients and found that, of these 56 patients, only 11 had been treated with acceptable errors of $\pm 5 \%$. The doses received by 28 of the 56 patients had errors ranging from +10 to $+105 \%$. These are the patients identified by ION physicists as overexposed. Twenty-three of the 28 overexposed patients had died by September 2005, with at least 18 of the deaths being from radiation effects, mostly rectal complications. The clinical, psychological, and legal consequences of the overexposures crippled cancer treatments in Panama and prompted PAHO to assess radiation oncology practices in the countries of Latin American and the Caribbean. ION clinicians evaluated the outcome of 125 nonoverexposed patients who had been treated in the same time period and for the same cancer sites as the overexposed patients. The clinicians uncovered a larger recurrence of cervical cancers than expected. The finding prompted PAHO to launch an initiative for the accreditation of radiation oncology centers in Latin America and the Caribbean, working in collaboration with professional societies for radiation oncologists, medical physicists, and radiotherapy technologists. The Latin American Association for Radiation Oncology (Asociación Latinoamericana de Terapia Radiante Oncológica) has established an accreditation commission. Accreditation will require that centers implement a comprehensive radiation oncology quality assurance program that follows international guidelines. Statistical data on patient outcomes will be collected in order to document needs in radiotherapy centers in Latin America and the Caribbean and to define future strategies for cancer treatment. 
TABLE 1. Chronology of events related to the investigation of the overexposure of radiation therapy patients at the National Oncology Institute (Instituto Oncológico Nacional, ION) of Panama

\begin{tabular}{|c|c|}
\hline Time period & Event \\
\hline March 2001 & $\begin{array}{l}\text { - Patient overreactions first reported; } 3 \text { deaths had occurred } \\
\text { - The ION medical physicists identify } 28 \text { cases with dosimetry errors } \\
\text { - The Ministry of Health of Panama requests assistance from the Pan American Health Organization (PAHO) } \\
\text { - PAHO's medical physicists calculate that the radiation dose received by the first deceased patient is more } \\
\text { than double the prescribed value }\end{array}$ \\
\hline April 2001 & $\begin{array}{l}\text { - PAHO's medical physicists calculate absorbed doses of } 28 \text { patients } \\
\text { - Experts from the M.D. Anderson Cancer Center confirm ION/PAHO findings and explain error with treatment } \\
\text { planning system manufactured by Multidata Systems International Corporation }\end{array}$ \\
\hline May 2001 & $\begin{array}{l}\text { - The ION reports problem to the Panamanian regulatory authority for radiation safety } \\
\text { - The International Atomic Energy Agency (IAEA) sends expert mission at the regulatory authority's request } \\
\text { - PAHO's lead medical physicist joins the IAEA team }\end{array}$ \\
\hline June-September 2001 & $\begin{array}{l}\text { - PAHO's medical physicists calculate } 11 \text { patients' brachytherapy doses } \\
\text { - PAHO's lead medical physicist reviews } 530 \text { patients' physics charts } \\
\text { - The United States Food and Drug Administration (FDA) investigates the Multidata software } \\
\text { - The IAEA publishes experts' report, Investigation of an Accidental Overexposure of Radiotherapy Patients in } \\
\text { Panama }\end{array}$ \\
\hline 2002 & $\begin{array}{l}\text { - ION's clinicians and PAHO's medical physicists undertake joint study of dosimetry and clinical outcome of } 153 \\
\text { patients } \\
\text { - PAHO launches initiative on accreditation of Latin American and Caribbean radiation oncology centers }\end{array}$ \\
\hline May 2003 & $\begin{array}{l}\text { - FDA issues an injunction to stop Multidata from manufacturing and distributing radiation therapy medical de- } \\
\text { vices in the United States } \\
\text { - Criminal trial of three local physicists starts in Panama }\end{array}$ \\
\hline June 2004 & $\begin{array}{l}\text { - Clinical effects in a cohort of cancer patients overexposed during external beam pelvic treatment, article by } \\
\text { PAHO and ION staff members, is published }\end{array}$ \\
\hline November 2004 & $\begin{array}{l}\text { - Two of the indicted physicists are sentenced to four years in prison and barred from practicing their profes- } \\
\text { sion for seven years; they appeal the sentence. The third physicist is acquitted. }\end{array}$ \\
\hline
\end{tabular}

Cancer is the leading cause of death in Panama. In a country with a population of some 2.8 million, more than 4000 new cancer cases are diagnosed each year (1). Treatments include surgery, chemotherapy, and radiation therapy. The country's largest radiation therapy institution is the National Oncology Institute (Instituto Oncológico Nacional). The ION is also Panama's only public radiation therapy institution.

The radiological health program ${ }^{2}$ of the Pan American Health Organization (PAHO) started providing technical assistance to the ION in November 2000 to review their plans to acquire new linear accelerators and expand the ION's radiation oncology services. In March 2001, Panama's Ministry of Health (Ministerio de Salud de la República de Panamá) asked PAHO to investigate some serious overreactions-including three deaths-among

\footnotetext{
2 The author, a medical physicist, was working in PAHO's radiological health program as a staff member until 2003, and as a consultant thereafter.
}

cancer patients undergoing radiation therapy treatment. PAHO's medical physicists ${ }^{3}$ carried out the investigation using information on radiation therapy treatment techniques and data from copies of patient charts provided by the clinical and medical physics staff at the ION. The actual chronology of the investigation is shown in Table 1.

After reviewing 530 treatment charts at the ION, PAHO's lead medical physicist ascertained that between 1 August 2000 and 2 March 2001, 478 cancer patients were treated at the ION. The cancer site treatment distribution for those 478 persons, according to ION's records, was: 71 breast, 40 brain, 38 lung, 67 head and neck, 3 bladder, 96 cervix, 13 colon, 19 endometrium, 48 prostate, 6 pelvis, and 77 other sites. Of these patients, 191 received teletherapy pelvic irradiation treatments, and 60 of them also received brachytherapy insertions. Of the

\footnotetext{
3 At the time, a second medical physicist, Damian Rudder, was working in PAHO's radiological health program as a consultant.
} 
191 patients, 153 of them were irradiated for tumors of the cervix, endometrium, uterus, prostate, or rectum. (This tumor site classification is the one used by the ION.) Until August 2000, these pelvic cancers had been treated with anterior/posterior (AP/PA) and lateral radiation fields without shielding blocks. To protect part of the small bowel and the femoral heads, in August 2000 the technique was modified to include corner blocks. A fifth block was sometimes also used to protect scar tissue in those patients who had undergone hysterectomies as part of their cancer treatment.

This modified treatment procedure was discontinued at the end of March 2001, after three deaths had occurred. By that time, the ION medical physicists had identified 28 patients who might have been overexposed. This paper reports on the managerial and dosimetric aspects of the investigation carried out by PAHO medical physicists in collaboration with the ION, and the resulting measures taken to alleviate the problem at the ION and to prevent a similar mishap elsewhere in the future. The dosimetric results were presented at medical physics conferences in $2001^{4}$ and $2002 .^{5}$ The clinical outcome of the cohort of 153 patients treated for the same cancer sites was published in 2004 (1).

\section{THE INVESTIGATION}

\section{Logistical aspects of radiation oncology at the National Oncology Institute}

In 1999, the ION moved all its services except radiation therapy from its location on Justo Arosemena Avenue in Panama City to the old Gorgas Hospital, located in Ancón, a neighborhood of Panama City located in the old Panama Canal Zone. ${ }^{6}$ The Gorgas Hospital had been a United States Army hospital before it was transferred to the Panamanian Government in 1997. When under United States Army control, the Gorgas Hospital had had a cobalt therapy room for radiation therapy treatments. Unfortunately, the structural shielding in the treatment room did not meet the 1995 Panamanian radiological protection regulations. ${ }^{7}$ Modification of the existing room would have required significant structural changes, which

\footnotetext{
4 Borrás C, Rudder D, Amer A, Hendry J. Sobreexposición de pacientes de radioterapia en Panamá-aspectos dosimétricos. On: CDROM. $2^{\circ}$ Congreso Iberolatinoamericano y del Caribe de Física Médica. Caracas: ALFIM; 2001.

5 Borrás C, Rudder D, Barés JP, Millán F. Overexposure of radiotherapy patients in Panama. [Abstract]. Med Phys. 2002:29(6);1326.

6 Personal communication, Juan Pablo Barés, ION.

7 República de Panamá. Ministerio de Salud. Resolución No 27. (De 24 de octubre de 1995). "Por medio de la cual se adopta las normas básicas de protección radiológica no. 110."
}

the architects contracted by the Ministry of Health of Panama decided were too difficult and costly to implement. Therefore, the Ministry of Health decided to keep the external beam therapy treatments in the old facility on Justo Arosemena Avenue, while brachytherapy treatments, patient hospitalization, and clinical follow-up of patients were to be performed in the remodeled Gorgas Hospital. The Gorgas Hospital became the new "National Oncology Institute." At the end of 1999, a project was developed by the ION to relocate the radiotherapy services into this remodeled facility and to purchase new, modern radiotherapy equipment. In December 2000, the Ministry of Health approved the project. $^{8}$

While the new radiotherapy facility was being built, external beam therapy treatments were given at the Arosemena Avenue site, from 6 a.m. to 9 p.m., using only a Theratron $780 \mathrm{C}$ cobalt unit, the source of which had been replaced in April 2000. In the same facility there was also a decommissioned ATC/9 Picker unit. The staff consisted of five radiation oncologists, six radiotherapy technicians, and three medical physicists. The radiation oncologists rotated between the two hospital facilities. Two of them were assigned to the Arosemena Avenue site for a month in two work shifts. The idea was that a radiation oncologist should always be present while patients were being treated, but, in practice, there was no physician on site after 6 p.m.

The treatment planning information for both external beam and brachytherapy treatments was kept in the "physics" patient data sheet at the Arosemena Avenue site. Clinical patient management was recorded in a "clinical" data sheet, which was kept in the Gorgas Hospital facility. Patients were seen at the Gorgas Hospital in the middle and at the end of the treatment, usually not by the same radiation oncologist who had prescribed the treatment.

\section{Treatment and dosimetry protocols}

Treatment planning and dose prescription were done at the Arosemena Avenue facility. Following published techniques $(2,3)$, most patients were treated with multiple fields on a daily basis, five days per week. Four of the five ION radiation oncologists treated pelvic fields without shielding blocks; the other oncologist required at least four blocks for the AP/PA fields. Between 1 August 2000 and 2 March 2001, a total of 153 ION patients were irradiated for tumors of the cervix, endometrium, uterus, prostate, or rectum; 56 of the 153 were treated using shielding blocks. Their can-

\footnotetext{
8 Personal communication, Juan Pablo Bares, ION.
} 
cer site distribution was as follows: 23 cervix, 20 prostate, 7 endometrium, 3 uterus, and 3 rectum. These 56 patients constitute the patient cohort of this investigation.

A review of the treatment charts-including the isodose distributions-for these 56 patients showed that all the pelvic irradiations used multiple treatment fields, but not all of the fields were blocked. For example, oblique fields and boost fields were not blocked, and that was also true in some cases for lateral fields. External beam doses prescribed for patients with cancer of the cervix, endometrium, or rectum were around $50 \mathrm{~Gy}$, with a central boost of 10-20 Gy for patients who only partially responded to the treatment. Prescribed doses to prostate tumors were 45-50 Gy to large field sizes, followed by a 20-Gy boost to a reduced field box technique or skip scan rotation, totaling between 65 and 70 Gy to the center of the tumor. Prescribed dose fractions ranged from 1.8 to 2 Gy per fraction. The radiation oncologists at the ION prescribed the dose either to the intersection of the radiation beams or to the isodose level that involved the tumor. The ION medical physicists performed the dosimetry calculations with a computerized radiation therapy treatment planning system (TPS) manufactured by Multidata Systems International Corporation (Saint Louis, Missouri, United States of America), with the isodose distributions and treatment times being generated using the "External Beam" Version 2.1.1 software for that TPS.

Depending on the stage of the disease, cancers of the cervix and the endometrium were treated both by external beam radiation therapy and by brachytherapy. Of the 56 patients in this study, 17 of them had received brachytherapy as well as external beam therapy. Brachytherapy was delivered using a manual afterloading technique with cesium-137 sources in Suit-Delclos applicators. The number, activity, and placement of the sources used depended on the clinical conditions (1).

According to Panamanian radiation protection regulations, ${ }^{9}$ patients undergoing brachytherapy treatments or nuclear medicine therapy procedures using iodine-131 needed to be hospitalized in specially shielded rooms. There were only four of these rooms in the new Gorgas site. Because of the large number of iodine-131 patients, the availability of these rooms for brachytherapy patients was limited. As a consequence, brachytherapy treatments could not be given in the middle of the external beam treatment course or immediately after

\footnotetext{
Personal communication, Eloy Gibbs, Caja del Seguro Social de Panamá, Departamento de Salud Radiológica, technical unit empowered by the Ministry of Health (the radiation regulatory authority) to develop and implement radiation protection regulations.
}

completing it, as many other institutions do. Often, brachytherapy was scheduled two to three months afterwards, when insertion in the uterine canal was difficult, and was frequently not done. To compensate for this lack of sources in the uterine canal, external beam fields were given a dose higher than recommended in published protocols (3). Patient treatment protocols were not documented, and individual patient cases were not referred to a tumor board, where the optimal treatment modality for that patient could have been considered by a multidisciplinary group of cancer physicians.

Starting in January 2001, brachytherapy insertions were quantified from a dosimetric point of view. The applicators loaded with dummy sources were inserted manually by a radiation oncologist in a minor surgery room at the new Gorgas site. The position of the applicators within the patient was then checked with a portable X-ray machine in the presence of a medical physicist, who filled out the appropriate data forms. Once the insertion geometry was approved by the radiation oncologist, the films were taken by the medical physicist to the Arosemena site and digitized into the TPS. Doses were individualized depending on the clinical stage of the disease. A typical prescription was $40 \mathrm{~Gy}$ to Point A (4); external beam doses to the whole pelvis were between 40 and 45 Gy. The TPS software program calculated doses to specified points, such as point $\mathrm{A}$, the bladder, and the rectum, and displayed the isodose curves.

\section{Identification of the computational error}

The first step taken in March of 2001 by the PAHO medical physicists, when they were alerted to a potential overexposure of patients treated with the cobalt-60 therapy unit at the ION, was to assess whether there had been a problem with the calibration of the unit, as had happened in Costa Rica in $1996(5,6)$. The ION was participating in the postal audit of the World Health Organization (WHO) and the International Atomic Energy Agency (IAEA) that verifies the calibration of radiotherapy beams in hospitals, using thermoluminescent dosimetry (TLD). Therefore, the PAHO medical physicists reviewed the TLD results for the ION cobalt-therapy unit. The last verification, which had been carried out in August 2000, had given an error of $4 \%$, which was within the $5 \%$ tolerance specified by the IAEA.

The PAHO medical physicists then calculated the dose to the first patient who had died in December 2000, using data from a copy of his treatment chart, made available by the ION. The physicists determined that the patient had received a 
dose of $94 \mathrm{~Gy}$, more than twice the prescribed dose of $40 \mathrm{~Gy} .{ }^{10}$ By mid-April 2001, the PAHO medical physicists calculated the doses received by 28 patients selected by the ION physicists as having possibly been overexposed. It is not known what criterion the ION physicists used for the selection. The standard of practice for dose delivery accuracy, set in 1976 by the International Commission on Radiation Units and Measurements, is $\pm 5 \%$ (7). The PAHO physicists found out that, except for one patient who had not completed the treatment at the ION, the delivered doses for the other 27 patients had errors that ranged from $10 \%$ to more than $100 \%{ }^{11}$ (In this paper, percentage error is defined by the difference between delivered dose and prescribed dose, divided by the prescribed dose, multiplied by 100).

At the end of April 2001, a team of experts from M.D. Anderson Cancer Center, in Houston, Texas, United States of America, was invited to Panama by the ION's director to investigate the problem. Those experts determined that the algorithm used in the TPS software gave treatment times differing by a factor of about two, depending on how the data for the partially shielded treatment fields were entered into the computer program. ${ }^{12}$ The instructions from the TPS manual were to enter the coordinates of the perimeter of the unshielded field and then to digitize one block at a time, to a maximum of four blocks. However, digitizing each block separately was time-consuming, and some of the radiation oncologists at the ION wanted to treat some cervix cancer patients with five blocks (one in each corner of the field and one over the hysterectomy scar). Therefore, the ION physicists circumvented the Multidata TPS software block entry limitations by digitizing all the blocks in a continuous fashion, as if it were a single block. When the outside and inside perimeters of the field were entered into the computer program in the same direction (performing a double loop), the computed treatment times were double those obtained when the outside perimeter was digitized in one direction and the inside perimeter in the reverse direction. The Multidata system did not alert the user that an improper data sequence had been entered.

These findings were confirmed in May 2001 by an IAEA expert team, which was sent to Panama at the request of the Panamanian regulatory au-

\footnotetext{
10 Borrás C. Preliminary point dose calculations for patients treated at the National Oncology Institute of Panama. Washington, D.C.: Pan American Health Organization; 2001. (PAHO report to the ION).

11 Borrás C. Patient dosimetry at the National Oncology Institute of Panama. Washington, D.C.: Pan American Health Organization; 2001. (PAHO report to the ION).

12 Aguirre F, Almond P, Lindberg R. Report of a consultation visit to the National Oncology Center, Panama City. Panama City; 2001. (Expert team report to the $\mathrm{ION}$ ).
}

thority for radiation safety (8). As the Ministry of Health of Panama had also invited PAHO, the IAEA team was joined in Panama by the PAHO lead medical physicist.

\section{Dose calculations}

The dosimetric assessment by the PAHO medical physicists fell into two categories: (1) external beam dosimetry for the 56 patients treated for cancer of the cervix, endometrium, uterus, prostate, or rectum and (2) brachytherapy dosimetry for 17 female patients treated for cancer of the cervix and/or endometrium. The dosimetry calculations, first performed in March and April 2001 at the PAHO Headquarters in Washington, D.C., were refined in the following months by this author after analysis of the information she had collected at the ION in May-June 2001. During that visit to Panama, she had reviewed 530 patient charts, from which a patient database, including dosimetric and clinical parameters, was generated.

\section{External beam dosimetry methodology}

The doses received by the 56 patients were assessed by performing manual point dose calculations at the point of intersection of the radiation beams. The following data were taken from the patients' charts for each treatment field: field sizes, attenuation factors for any beam modifiers used (e.g., blocking and/or wedges), depth of the point of intersection of the treatment fields from the patient's skin surface, treatment times, and radiation output of the cobalt- 60 unit. Backscatter factors and percentage depth doses to the points of calculation for each treatment field were taken from published tables (9). Calculations were also performed for all patients whose clinical outcomes showed significant complications, for unusually heavy patients, and on a spot-check basis. Each patient record was carefully reviewed. Since patient field sizes and depths were similar, the parameter most closely examined was the treatment time per dose fraction for each field.

By May 2001 the ION physicists had produced two sets of isodose distributions for each of the 28 overexposed patients. One set, generated at the onset of treatment, was the result of entering the block coordinates by the double-loop method. For the second set, which was generated retrospectively, the block coordinates were entered individually. The two sets of isodoses were analyzed by the PAHO medical physicists. Figure 1 compares the resulting isodose distributions for a particular patient when the coordinates for the shielding blocks 
FIGURE 1. Comparison of isodose distributions for a rectum four-field treatment plan for a radiation therapy patient when the coordinates for the shielding blocks were incorrectly entered in the computerized radiation therapy treatment planning system using the double-loop method (Figure 1a) and when the coordinates for each block were correctly digitized individually (Figure 1b), with the block configuration given in Figure 1b for both treatment plans, National Oncology Institute, (Instituto Oncológico Nacional, ION) of Panama, 2000-2001

FIGURE 1a. Double-loop method; the computed treatment time per dose fraction was 1.01 minute

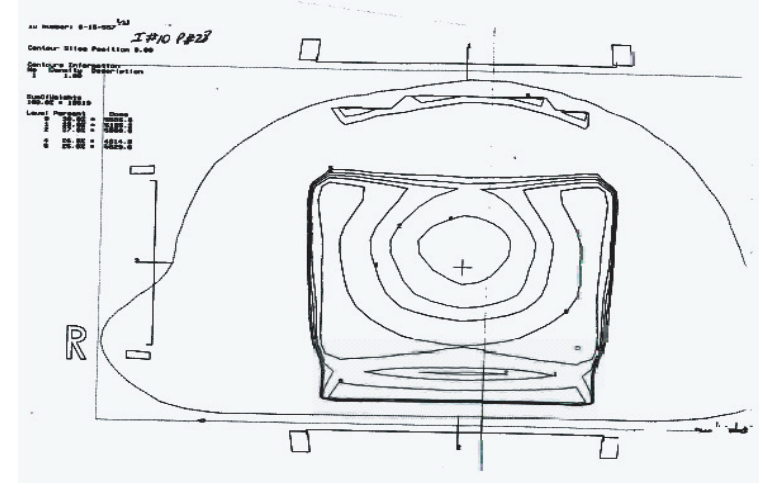

FIGURE 1b. The coordinates for each block entered separately; the computed treatment time per dose fraction was 0.50 minute

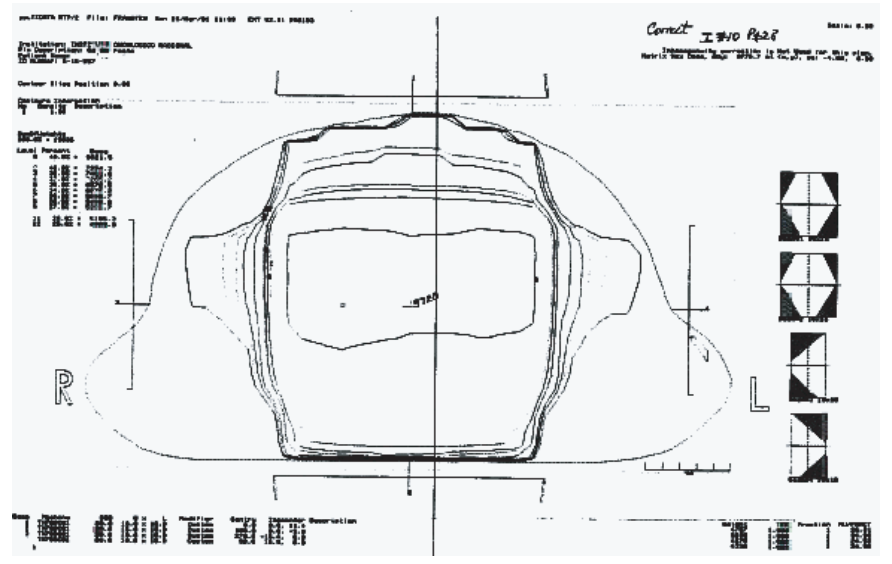

were entered in the TPS using the double-loop method (Figure 1a), and when the coordinates for each block were digitized individually (Figure 1b). (This isodose distribution was chosen by this author as the most illustrative example among the two sets of isodose distributions that the ION physicists had generated for each of the 28 patients they studied.) The ION physicists did not notice that the shape of the isodoses generated by the double-loop method (Figure 1a) did not resemble typical isodose curves for that particular type of treatment (Figure 1b). Had they realized this at the time the patients were treated, they would have uncovered the problem with the TPS sooner.

Manual calculations were done for the 17 patients who had received brachytherapy, using the data supplied with the patients' charts, including the number of sources used, their arrangement, and their activity (10). Assuming typical anatomical dimensions (1), doses were determined to point A, the bladder, and the rectum. The ION brachytherapy prescription, in mgh of radium, was converted into Gy by multiplying the mgh by 0.9 , following Perez et al. (11).

As was mentioned earlier, 153 ION patients were irradiated for tumors of the cervix, endometrium, uterus, prostate, or rectum between 1 August 2000 and 2 March 2001; 56 of these 153 patients were treated using shielding blocks and had their treatment times improperly calculated. However, not all of these incorrect treatment-time calculations led to doses exceeding the $\pm 5 \%$ accuracy tolerance. By chance, the double-loop calculation method was used only in half of the 56 cases. Teletherapy and approximate brachytherapy absorbed doses to the tumors of these 56 patients have been published (1). Figure 2 is a histogram of the percentage errors found in the teletherapy absorbed doses received by the 56 patients whose treatment times were calculated by digitizing the blocked field using a single outline. The histogram shows the number of patients with absorbed dose errors, with 5\%-error intervals; the absorbed dose errors range from $-5 \%$ to $+105 \%$. The mean error for the doses received by the 
Figure 2. Errors in absorbed doses of teletherapy treatments received by 56 patients (percentage error $(\%)=[($ delivered dose - prescribed dose)/prescribed dose $\times 100)$, National Oncology Institute (Instituto Oncológico Nacional, ION) of Panama, 2000-2001

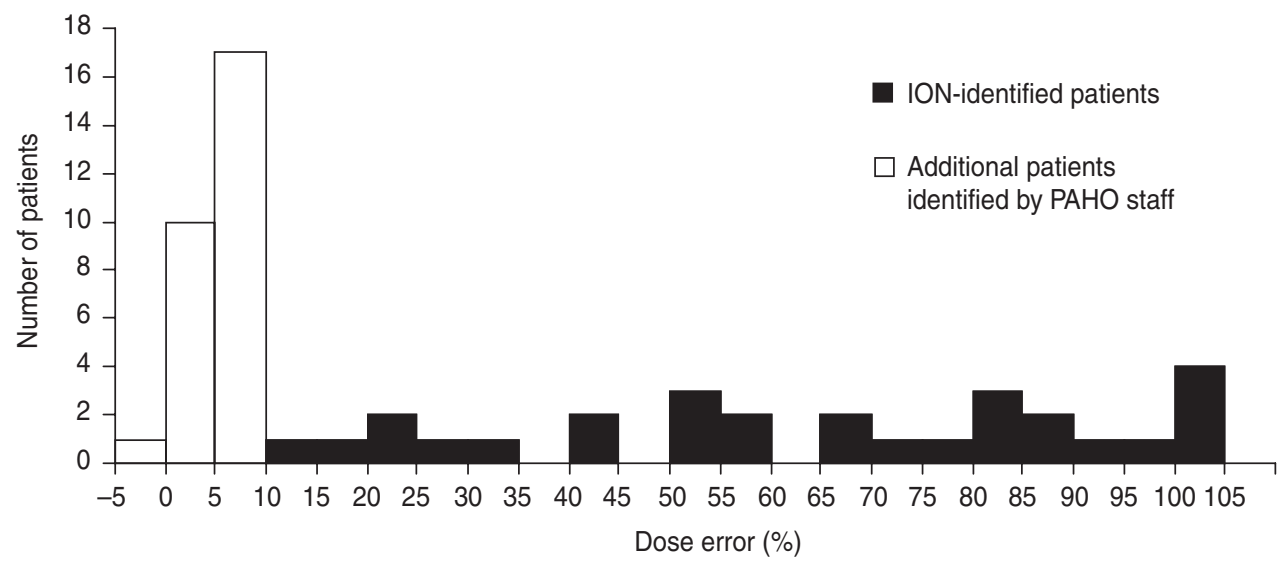

28 patients identified by the ION physicists as overexposed (their treatment times had been calculated by the double-loop method) had a mean value of $+65 \%$, with a standard deviation of $29 \%$. Among these 28 patients, there was one who had initiated prostate treatment in November 2000 at the ION and, because of intestinal complications, interrupted his treatment after six sessions and completed the treatment at a private center shortly thereafter. At that private center the medical physicist (the same medical physicist working at the ION) calculated the treatment time by taking the ratio of dose rates of the ION cobalt unit and that of the private center cobalt unit, without realizing that an error had occurred in the original treatment time determination. An earlier report (8) indicated that the patient had not completed the treatment and therefore had not been overexposed. The PAHO medical physicists found out that, while the prescribed dose was $65 \mathrm{~Gy}$, the dose received was $93 \mathrm{~Gy}(1)$, not $19.35 \mathrm{~Gy}$, as originally reported (8).

The mean absorbed dose error for the 28 additional patients identified by the PAHO physicists as having had their treatment times also calculated by the TPS was $+6 \%$, with a standard deviation of $2.5 \%$. These patients also had their block coordinates entered as a single outline, but the internal and external perimeters of the blocked field were digitized in reverse directions.

In summary, of the 56 patients, only 11 received doses within the accepted $\pm 5 \%$ tolerance. How many were overexposed? Did the ION physicists use the $+10 \%$ error as the criterion for overexposure? The International Commission on Radiological Protection (ICRP) says that " $10 \%$ or more overdosage should be detected by a well-trained clinician, based upon an unusually high incidence of adverse patient reactions" (12). The Nuclear Regulatory Commission of the United States used to call a $10 \%$ deviation between a prescribed and delivered dose a "misadministration" (13), but because of the potential implication of "malpractice," the term "medical event" is now used, with a $20 \%$ tolerance for an overall treatment, and 50\% for a dose fraction in a series (14).

In order to be consistent with previous publications $(1,8,15)$, this paper will use the term "overexposed patients" to refer to the cohort of 28 patients originally identified by the ION physicists as overexposed.

\section{CLINICAL DOSE EFFECTIVENESS AND EVALUATION OF OVEREXPOSED PATIENTS' CLINICAL OUTCOME}

From a radiobiological perspective, total absorbed doses are not the only important variable; high doses per fraction enhance the radiobiological response, especially for late-responding normal tissues (16). To take this fact into account, clinical doseeffectiveness calculations use the concept of biologically effective dose (BED). The BED is the maximum dose equivalent using very low doses per fraction or low dose rates. This useful concept incorporates in the calculations the estimated cell repair times, and allows comparisons to be made of the effects of doses delivered using different fractionation regimes. It also allows external beam and brachytherapy doses to be combined. Alternatively, both treatment doses can be converted to the equivalent dose delivered in conventional 2-Gy fractions (1). 


\section{Status of overexposed patients by May 2002}

The clinical dose effectiveness and the clinical outcome of the 56 patients included in this study were determined as part of a clinical investigation of a total of 153 patients who had received external beam radiotherapy to the pelvis at the ION during the same time period, August 2000 to March 2001; that information was published in June 2004 (1). The investigation was performed along the lines established by the IAEA for the overexposed patients one year earlier (8), but it extended the study by analyzing normal tissue (colon and bladder) reactions using both the RTOG (17) and the LENT/SOMA (18-20) scoring methods. (RTOG and LENT/SMA are the acronyms for "Radiation Therapy Oncology Group" and "late effects on normal tissues"/"subjective symptoms, objective signs, management, and analytical measures")

By May 2002, 17 of the 28 overexposed patients had died within 35 days to 21 months after being treated. Thirteen of the fatalities were caused by rectal complications. Death started occurring when rectal doses reached the equivalent of 70-80 Gy in 2-Gy fractions (rectal BED values greater than 120-130 Gy). After doses equivalent to $130 \mathrm{~Gy}$ in 2-Gy fractions (rectal BED values of $200 \mathrm{~Gy}$ ), all the patients died (1). The patients who died in the first few months after treatment had severe injury in the small and large intestine, which resulted in a high level of secondary sepsis. The patients who died later, approaching one year after radiotherapy, had damage in the large bowel, resulting in obstructions, necrosis, and perforation (1). Two of the three patients who had been treated with five blocks instead of four survived longer, as did the patients who had received colostomies (1).

\section{Status of overexposed patients after May 2002}

The surviving patients continued to be followed up clinically at the ION. Information on their status was obtained by the author in June 2004, November 2004, and August 2005. By June 2004, 21 of the 28 overexposed patients had died. Seventeen of these deaths could be ascribed to radiation effects. ${ }^{13}$ There was also additional morbidity. One of the cervical cancer patients, who had received an absorbed dose of 92 Gy to the pelvis from the external beam treatment and 25 Gy from brachytherapy, developed spastic gait in August 2002, 23 months after the end of the teletherapy treatment. She was

\footnotetext{
13 Personal communication, Fernando Millán and Juan Pablo Barés, ION, November 2004.
}

diagnosed with bilateral motor and sensory radiculopathy affecting L1-L4. In February 2003, the neurophysiological lumbosacral plexopathology was confirmed and attributed to the radiation therapy overexposure. By April 2004, 32 months after the end of the radiation therapy treatment, the patient had developed total paraplegia of the lower limbs. By November 2004, she had died; the exact date of her death was not recorded at the ION.

By August 2005, 23 patients had died, at least 18 of them from radiation effects, mostly rectal complications. The 5 surviving overexposed patients continue being followed up by and receiving medical care from ION physicians. Their clinical condition, as of August 2005, is shown in Table 2. ${ }^{14}$ The patients all suffer from gastrointestinal ailments; one of them had to undergo a colostomy. Based on previous clinical experiences (21), they are expected to develop more late effects over the coming years.

\section{Comparison with overexposure in Costa Rica in 1996}

The morbidity and mortality found in the Panama study are consistent with the data in the literature $(12,22,23)$. Of particular interest, because of its geographical and cultural proximity, is the Costa Rica case that occurred in $1996(5,6)$.

In the San Juan de Dios Hospital, a facility of the Costa Rica Social Security Agency (Caja Costarricense de Seguro Social) in San José, Costa Rica, a physicist made a mistake in the calibration of a cobalt- 60 unit. He interpreted decimals of minutes as seconds, and provided the facility with dose rate charts that were in error by $45 \%$. The miscalculation resulted in the overexposure of 114 radiotherapy patients between 26 August and 27 September 1996. The overexposure was studied by PAHO and the IAEA $(5,6)$. Patient outcome was evaluated weeks after (5), one year after (6), and two years after $(24,25)$ the completion of the radiotherapy treatment. Of the 114 overexposed patients, 35 of them had received pelvic doses from 40 to $70 \mathrm{~Gy}$ in numbers of fractions ranging from 12 to 25 , and doses per fraction from 2.7 to $5 \mathrm{~Gy}$, about $60 \%$ higher than prescribed. Six of these patients died between 6 weeks and 13 months after treatment from one or more of the following complications: bowel fistulas, perforation, intestinal necrosis, and peritonitis. These complications were the same as the ones that occurred in the overexposed patients in Panama (1), but the morbidity and mor-

\footnotetext{
14 Personal communication, Juan Pablo Barés and Fernando Millán, ION, August 2005.
} 
TABLE 2. Radiotherapy doses that had been prescribed and received at the National Oncology Institute (Instituto Oncológico Nacional, ION) of Panama between August 2000 and March 2001 and the clinical condition of the five surviving overexposed patients as of August 2005

\begin{tabular}{|c|c|c|c|c|c|}
\hline Patient number ${ }^{a}$ & 7 & 13 & 15 & 18 & 24 \\
\hline $\begin{array}{l}\text { Cancer site } \\
\text { Prescribed tumor absorbed dose (Gy) }\end{array}$ & Endometrium & Prostate & Endometrium & Prostate & $\begin{array}{l}\text { Uterine } \\
\text { cervix }\end{array}$ \\
\hline Teletherapy & 50 & 45 & 45 & 45 & 45 \\
\hline Brachytherapy & 18 & $-^{\mathrm{b}}$ & 14 & - & 21 \\
\hline \multicolumn{6}{|l|}{ Received tumor absorbed dose (Gy) } \\
\hline Teletherapy & 79 & 54 & 77 & 54 & 49 \\
\hline Brachytherapy & 16 & - & 13 & - & 19 \\
\hline \multicolumn{6}{|l|}{ Biological effective dose (BED) (Gy) } \\
\hline Tumor: $\alpha / \beta=10 ;(\alpha / \beta=1.5)$ & 123 & $71(167)$ & 116 & 73 (132) & 83 \\
\hline Bladder: $\alpha / \beta=5$ & 152 & 88 & 141 & 92 & 98 \\
\hline Rectum: $\mathrm{BED}_{1} \alpha / \beta=10$ & 118 & 71 & 112 & 73 & 77 \\
\hline Rectum: $\mathrm{BED}_{2} \alpha / \beta=3$ & 186 & 110 & 174 & 118 & 116 \\
\hline \multicolumn{6}{|l|}{ 2-Gy/fraction dose-equivalent (Gy) } \\
\hline Tumor: $\alpha / \beta=10 ;(\alpha / \beta=1.5)$ & 102 & $59(71)$ & 97 & $61(78)$ & 69 \\
\hline Bladder: $\alpha / \beta=5$ & 108 & 63 & 101 & 66 & 70 \\
\hline Rectum: $\mathrm{BED}_{1} \alpha / \beta=10$ & 98 & 59 & 94 & 61 & 64 \\
\hline Rectum: $\mathrm{BED}_{2} \alpha / \beta=3$ & 111 & 66 & 104 & 71 & 69 \\
\hline Clinical findings as of August 2005 & $\begin{array}{c}\text { Diffuse pain } \\
\text { of the } \\
\text { gastrointestinal } \\
\text { tract }\end{array}$ & $\begin{array}{l}\text { Surgery for } \\
\text { cancer of } \\
\text { ascending colon; } \\
\text { stable condition }\end{array}$ & $\begin{array}{l}\text { Frequent urinary } \\
\text { infections; } \\
\text { vaginal fistula }\end{array}$ & $\begin{array}{l}\text { Colostomy for } \\
\text { actinic colitis }\end{array}$ & $\begin{array}{c}\text { Stable } \\
\text { condition }\end{array}$ \\
\hline
\end{tabular}

a The patient numbers are taken from Table 2 of Borrás et al. (1).

b The "-" symbol indicates that the patient did not receive brachytherapy.

tality in Costa Rica were less severe than in Panama because the doses were lower.

\section{PLANNED ACCREDITATION PROGRAM FOR LATIN AMERICAN AND CARIBBEAN RADIATION ONCOLOGY CENTERS}

The clinical study performed in May 2002 and published in June 2004 (1) had a cohort of 153 patients; 28 of them constituted the overexposed group, and 125 made up the control group. Clinical follow-up was performed on 98 of these 125 patients. The most interesting finding was the high incidence of tumor recurrence among patients in this control (non-overexposed) group with cervical and endometrial cancer, especially for cancer stages 1 and 2 (1). This suggested that either the teletherapy field margins were not set up optimally (26) or that the doses were not high enough (27). The latter conclusion is supported by the fact that tumor activity was found only among patients who had no rectal complications. However, both the teletherapy and brachytherapy absorbed doses were within published recommended ranges (2-4). Recurrences for cancer of the cervix have been reported extensively (28-31). The literature review of Hendry et al. (32) indicates that there is a $5.6 \%$ loss of tumor control for each week of additional treatment duration.
This amounts to a $22 \%$ loss of tumor control for each month of additional treatment duration. Hence, the gap of one or more months between the teletherapy and brachytherapy treatments, caused by the scarcity of hospital beds in the specially shielded rooms at the Gorgas Hospital, could well have had a detrimental effect on the outcome. Perez et al. showed that after the initial treatment for cancer in any stage, $80 \%$ of recurrences appear within 24 months (33).

The unexpectedly high level of cervical cancer recurrence among the ION patients prompted the PAHO medical physicists to evaluate cancer recurrence in other cancer centers in Latin America and the Caribbean, and to compare those findings with published results. The PAHO medical physicists contacted the officers of two radiation oncology professional societies, the Group of Iberian and Latin American Radiation Oncologists (Círculo de Radioterapeutas Ibero-Latinoamericanos) and the Latin American Group of Brachytherapy-Oncological Radiation Therapy (Grupo Latinoamericano de Curieterapia-Radioterapia Oncológica). The PAHO medical physicists also contacted the directors of some large radiation oncology facilities, including the National Cancer Institute of Colombia, where a comprehensive evaluation of its 43 radiation oncology centers had been conducted with PAHO's support (34). The PAHO medical physicists hoped to be 
able to collect data from these professional societies and national cancer institutes that would allow them to analyze the results of representative clinical quality-assurance practices, in particular those dealing with patient follow-up.

The evaluation of the Colombia radiation oncology centers showed that the centers did not have documentation on long-term patient follow-up (34). The officers of the two radiation oncology professional societies reported the same kind of information: In most countries of Latin America and the Caribbean, assessment of clinical outcome, and therefore of radiotherapy success or failure, is performed by the referring physicians.

This prompted PAHO in 2002 to launch an initiative on the accreditation of radiotherapy departments in Latin America and the Caribbean. This was done in collaboration with the two radiation oncology societies mentioned above, and with two other organizations, the Latin American Medical Physics Association (Asociación Latinoamericana de Física Médica) and the International Society for Radiographers and Radiological Technologists. The objective of the initiative was to promote a cultural change in the countries of Latin America and the Caribbean, towards an acceptance of external evaluations of radiation oncology services as a mechanism for raising and standardizing the quality of radiation oncology practices.

In 2005 the two Latin American and Caribbean radiation oncology societies merged to form one association, the Latin American Radiation Oncology Association (Asociación Latinoamericana de Terapia Radiante Oncológica) (35). To improve the quality of standards in the health care of cancer patients undergoing radiation therapy treatments in Latin America and the Caribbean, the Association officers decided to set up the "Commission on Accreditation of Radiation Oncology Centers." The Commission's goal is to increase the survival rates for and the quality of life of oncological patients, by better controlling tumors and by reducing the complications and toxicity due to radiation therapy.

The Commission on Accreditation is expected to be fully functional by 2007. The Commission's first task is to develop accreditation criteria for all the stages of the radiotherapeutic process: clinical history, diagnosis and staging of the disease, therapeutic decision, localization/simulation of the treatment, physical and clinical dosimetry, teletherapy/ brachytherapy treatments, and clinical follow-up and statistics. Of main concern is the adequacy of treatment protocols. Are patients receiving doses high enough to ensure cancer control and to improve survival? Are radiation oncologists reluctant to cause even a small and normally acceptable per- centage of patient overreactions? Are radiation oncologists prescribing doses lower than what is recommended in the literature? Is the fear of violating radiation safety regulations affecting decisions regarding patient treatment?

The Commission on Accreditation will pay particular attention to clinical patient follow-up procedures in order to ensure that radiation late effects are documented, and that appropriate patient support is provided. Centers will only be accredited if they have implemented a comprehensive quality assurance program that follows international guidelines (36-38). Statistical data on patient outcome will be collected in order to document needs in Latin American and Caribbean radiotherapy centers and to define future strategies for cancer treatment. The Commission will also identify a cadre of radiation oncology experts to audit the centers that wish to be accredited.

\section{CONSEQUENCES OF THE PANAMA OVEREXPOSURES}

The lessons from the Panama overexposures are not limited to how to manage the affected patients. Regulatory authorities in Panama and in the United States and two international organizations launched a series of investigations to help prevent future occurrences of this type of "accident." A key question is, were all the overexposures at the ION really an "accident"? And what does "accident" mean? One dictionary defines "accident" as "chance or what happens by chance." The IAEA defines "accident" as "any unintended event, including operating errors, equipment failures, or other mishaps, the consequences or potential consequences of which are not negligible from the point of view of protection or safety" (12). The ICRP defines the term as "an unintended event that has or may have adverse consequences" (22). When dealing with medical exposures, both the IAEA and the ICRP also use the term "accidental medical exposures." One of the connotations is that of a dose or dose fractionation differing substantially from the values prescribed by the medical practitioner. In these latter definitions, "accidental" has the connotation of unintended and not unexpected, with an emphasis on the difference between prescribed and delivered. Somehow it is assumed that the prescribed dose is correct and that "adverse effects" are rare. However, to cure cancer, a certain percentage of "adverse effects" may occur in normal tissues at a level that is accepted in medical practice. This includes up to $1 \%$ of patients who are very radiosensitive because of various repair-deficiency 
TABLE 3. Major accidental exposures of radiotherapy patients that have happened around the world over the last three decades $^{\mathrm{a}}$

\begin{tabular}{|c|c|c|c|}
\hline Type of accident & Country & Year(s) & $\begin{array}{l}\text { Patients overdosed } \\
\text { or underdosed }\end{array}$ \\
\hline Miscalibration of cobalt- 60 units & $\begin{array}{l}\text { United States } \\
\text { Germany } \\
\text { United Kingdom } \\
\text { Costa Rica }\end{array}$ & $\begin{array}{l}1974-1976 \\
1986-1987 \\
1988 \\
1996\end{array}$ & $\begin{array}{r}426 \text { overdosed } \\
86 \text { overdosed } \\
207 \text { overdosed } \\
114 \text { overdosed }\end{array}$ \\
\hline $\begin{array}{l}\text { Hardware/software problems } \\
\text { with linear accelerators }\end{array}$ & $\begin{array}{l}\text { Canada and United States } \\
\text { Spain } \\
\text { Poland }\end{array}$ & $\begin{array}{l}1985-1987 \\
1990 \\
2001\end{array}$ & $\begin{array}{r}3 \text { overdosed } \\
27 \text { overdosed } \\
5 \text { overdosed }\end{array}$ \\
\hline Low dose rate brachytherapy problems & $\begin{array}{l}\text { United Kingdom } \\
\text { United States }\end{array}$ & $\begin{array}{l}1988-1989 \\
1992\end{array}$ & $\begin{array}{l}14 \text { underdosed } \\
12 \text { overdosed } \\
1 \text { overdosed }\end{array}$ \\
\hline Treatment planning errors & $\begin{array}{l}\text { United Kingdom } \\
\text { United States } \\
\text { Panama }\end{array}$ & $\begin{array}{l}1982-1990 \\
1987-1988 \\
2000-2001\end{array}$ & $\begin{array}{c}1045 \text { underdosed } \\
33 \text { overdosed } \\
28 \text { overdosed }\end{array}$ \\
\hline
\end{tabular}

a The data presented in the table come from IAEA (12) and ICRP (22).

syndromes. ${ }^{15}$ Both the IAEA and the ICRP have published reports that illustrate different types of accidents and their root causes $(12,22)$. Table 3 lists major instances of radiotherapy accidents that have happened around the world over the last three decades. While most of the incidents involve overexposures, there have also been several instances of patients being underdosed, leading to lack of cancer control. The most notable case of underexposure occurred from 1982 to 1990 in the United Kingdom, at the North Staffordshire Royal Infirmary, in the city of Stoke-on-Trent in the county of Staffordshire. It was due to an incomplete understanding and testing of a treatment planning system (12). Of the 1045 improperly treated patients, 492 of them developed local recurrences (39).

Cancer recurrence is not the concern of radiation regulatory authorities. Those regulatory authorities only investigate overexposures (often without understanding the clinical aspects of radiation therapy), and they assign the responsibilities for patient treatment to the physicists performing the dosimetry. Two key publications, the International basic safety standards for protection against ionizing radiation and for the safety of radiation sources (40) and the EU Council Directive 97/43/Euratom (41), emphatically state that medical exposures are the responsibility of the medical practitioner prescribing or delivering

${ }^{15}$ Hendry JH, Zubizarreta EH. Variation in biologically-effective dose (BED) prescriptions among centres using brachytherapy/externalbeam treatment of cervical cancer [abstract]. Radiother Oncol. 2004: 73(Supplement 1):S19. the dose. However, since errors are clearly doserelated $(5,6,8,12,22,24,25)$, physicists are being taken to court for radiation therapy overexposures, while the physicians in charge are not being charged (42-45).

\section{Regulatory actions}

The Panamanian regulatory authority for radiation safety investigated the overexposures immediately after receiving notification from the ION. The "lessons learned" generated a series of corrective actions, among them stringent requirements for the establishment of quality assurance and quality control programs, and for adequate training of professionals of the ION's radiation oncology department (46).

The Center for Devices and Radiological Health of the United States Food and Drug Administration (FDA), which oversees medical devices, approved Multidata's TPS software in 1997. In May-June 2001, right after the FDA became aware of the Panama overexposures, the FDA sent examiners to investigate Multidata. The FDA found that Multidata had received at least six complaints about calculation errors related to the failure of the firm's radiation treatment planning software to correctly handle certain types of blocks (polygons) (47). The FDA also found out that even the most recent version of Multidata's TPS algorithm was capable of the same error. Consequently, the FDA forced the company to issue a warning to all its TPS 
users, in order to prevent any other accidental overexposures (48).

The FDA found that Multidata had failed to: (1) establish, maintain, and follow procedures to control the design of the radiation treatment planning software in order to ensure that the specifications were met; (2) establish and follow procedures for taking preventive and corrective action; (3) establish and follow procedures for investigating all complaints; and (4) adhere to other standard good manufacturing practices. In addition, the firm failed to identify the root cause of the software code problems when they were brought to the company's attention.

The Nuclear Regulatory Commission (NRC) of the United States published the findings of the IAEA investigation in an "information notice" dated 20 November 2001. The NRC sent the notice to all its medical licensees, and attached the June 2001 and August 2001 "urgent notices" that Multidata had sent to its customers in response to the FDA's action (49).

\section{Legal actions}

On 18 May 2004 a court trial for the three ION physicists began in Panama City. The prosecutor had asked for them to be convicted of seconddegree murder. Neither the ION nor the five radiation oncologists involved were charged. On 18 November 2004 it was announced that one of the physicists was acquitted, but the other two were found guilty, sentenced to four years in prison, and barred from practicing their profession for seven years (45). They have initiated an appeal process, but they are very worried, given the precedent established by the Costa Rica case.

The trial for the Costa Rican physicist who had miscalibrated the cobalt therapy unit began on 26 February 2000, in the presence of 35 surviving patients and the relatives of 80 patients who had died. He was accused of negligence in 30 homicides and 59 radiation injuries. He was also accused of falsifying documents and of using false documents. On 30 July 2001 he was absolved of the latter two charges, but he was found guilty of 14 homicides and 50 radiation injuries. He was sentenced to six years in prison and barred from practicing his profession for five years. The plaintiffs had also sued the Costa Rica Social Security Agency, claiming that the indemnifications paid to them by the Agency did not preclude them from obtaining additional compensation from the Agency in connection with the overexposures. The court ruled against the plaintiffs and in favor of the Agency. Both decisions were appealed to the Supreme Court of Costa Rica. On 12 August 2003 the Supreme Court upheld the verdict and the sentence of the lower court regarding the physicist's culpability. The Supreme Court, however, overturned the lower court's decision precluding the plaintiffs from seeking additional compensation from the Agency (44). This decision cleared the way for surviving patients or their heirs to file suit against the Agency in civil court.

Plaintiffs from Panama also sued Multidata, both in the state of Missouri (United States) and in Panama. The Missouri court dismissed the action, concluding that the case could have and should have been brought up in Panama. The court cited a variety of reasons, such as the fact that the ION could not be sued in Missouri and that it would be highly inconvenient to conduct pretrial discovery if the case were pending in the United States (50). The Panamanian court dismissed the charges brought against Multidata, saying that the case had been filed in two courts simultaneously (43). Now that the case has been dismissed in the United States, the plaintiffs are free to again sue Multidata in Panama. Depending on the outcome of the litigation, the potential judgment could be substantial. In the Stoke-on-Trent (United Kingdom) case, 80 of the 492 patients who developed local recurrences sued the North Staffordshire Health Authority, alleging that tumor recurrence was due to underexposure. They won the suit and were awarded a total of $£ 2$ million (39).

\section{THE NATIONAL ONCOLOGY INSTITUTE TODAY}

Many things have changed at the ION since the patient overexposures occurred. The radiation oncology department has moved into a new building within the remodeled Gorgas Hospital. New treatment rooms have been built with the structural shielding specified by the Panamanian regulations. Thanks to a donation of US\$ 6.5 million made by the Government of Taiwan to the Government of Panama, the equipment now consists of three linear accelerators (two of them with dual energy photons and electrons), a superficial X-ray machine, a simulator, and a treatment planning system. Except for the superficial X-ray machine, all the units are networked. Access to a computed tomography scanner for virtual simulation is also available. The staff consists of six radiation oncologists, five physicists, four dosimetrists, and 12 radiation therapy technologists. The ION also has a radiological protection department, with 1.5 full-time-equivalent staff. The quality and safety of the radiation therapy procedures are monitored by the Inter-institutional Committee on Radiological Protection and Quality Control (Comité 
Interinstitucional de Protección Radiológica y Control de Calidad), which meets weekly. The Committee is composed of members of the ION's radiology, radiation oncology, nuclear medicine, and radiological protection departments, and it is chaired by the ION's director. Although it was established in response to the radiotherapy overexposures, it now oversees all the activities that involve ionizing radiation.

\section{CONCLUSIONS}

The Panamanian overexposure incident is perceived as one of the worst radiation therapy accidents ever. It had devastating consequences, not just for the patients but also for the practice of radiation therapy in Panama. As had happened in other patient overexposures, such as the ones in Costa Rica, patients in Panama began avoiding the public institution and instead sought treatment in private facilities. They did not realize, however, that because of staffing shortages, the same radiation therapy personnel worked in both the public and private facilities.

While the Panama overexposures were caused by a violation of the TPS instructions, a good software program would have alerted the user that the procedure was not authorized. In any case, treatment times generated by a TPS require manual verification. However, no TPS quality control existed at the ION, even though a comprehensive report on quality assurance for TPSs was available at the time (51). This experience prompted the IAEA to publish a report that describes how to commission a TPS, and with what frequency its algorithms should be tested (52).

There were other factors that contributed to the error with the TPS at the ION. One was the large patient workload, with more than 70 patients per machine per day. Another factor was that teletherapy treatments were done in one hospital (where the physics charts were kept), and brachytherapy treatments and patient follow-up were done (and clinical charts kept) in another hospital. The shortage of medical physics staff also played a significant role.

Radiation-safety regulatory authorities investigate accidental medical exposures, focusing on overexposures. However, the most interesting finding in Panama was the high level of recurrence of cervical cancer among the patients for whom no unacceptable error in dose delivery had occurred. The finding prompted PAHO to launch an initiative for the accreditation of radiation oncology centers in Latin America and the Caribbean. Accreditation will require that the centers implement a comprehensive radiation oncology quality assurance program that follows international guidelines. Statistical data on patient outcome will be collected in order to document needs in Latin American and
Caribbean radiotherapy centers and to define future strategies for cancer treatment (1). The newlyestablished Commission on Accreditation should ensure that cancer patients are treated with doses that are not only "safe" but effective.

Acknowledgements. We are indebted to the staff of the ION, especially to Juan Pablo Barés, who was the director of the ION and who encouraged this research, as well as the radiation oncology personnel, who kindly made procedure information and patient data available. We thank Damian Rudder, who, while at the Pan American Health Organization, performed all the absorbed dose calculations; Jolyon Hendry, who reviewed earlier drafts of this work and offered helpful suggestions throughout; and William Roventine, who reviewed the last drafts.

\section{SINOPSIS}

\section{La sobreexposición de pacientes tratados con radioterapia en Panamá: reconocimiento del problema y medidas de seguimiento}

Este informe resume y analiza la respuesta de varias organizaciones que brindaron asistencia al Instituto Oncológico Nacional (ION) de Panamá después de la sobreexposición de 28 pacientes sometidos a radioterapia que ocurrió en el ION a finales de 2000 y principios de 2001. Además, se examinan las medidas de largo plazo adoptadas en el ION en respuesta al accidente de sobreexposición y las implicaciones que tiene este accidente para todos los centros de tratamiento oncológico en el mundo. En marzo de 2001 se le comunicaron al director del ION las reacciones adversas graves sufridas por algunos pacientes sometidos a radioterapia contra el cáncer. De los 478 pacientes tratados entre agosto de 2000 y marzo de 2001 por cánceres localizados en la región pélvica, tres habían fallecido, presumiblemente por sobredosis de radiación. A raíz de ello, el Gobierno de Panamá invitó a expertos internacionales a realizar una investigación a fondo de la situación. Entre los especialistas invitados se encontraban físicos médicos de la Organización Panamericana de la Salud (OPS), quienes comprobaron que 56 pacientes con cáncer cérvico-uterino, de endometrio, de próstata o de recto tratados mediante campos de teleterapia parcialmente bloqueados recibieron dosis calculadas mediante un sistema computarizado de planificación de tratamientos. Los físicos médicos de la OPS comprobaron que solo 11 de esos 56 pacientes recibieron una dosis absorbida dentro de los límites aceptables de $\pm 5 \%$. Veintiocho de los 56 pacientes recibieron dosis con errores entre $+10 y+105 \%$. De esos 28 pacientes que fueron sobreexpuestos, según los físicos del ION, 23 murieron antes de septiembre de 2005; de ellos, 18 murieron a causa de los efectos de las radiaciones, principalmente complicaciones rectales. Las consecuencias clínicas, psicológicas y jurídicas de esta sobreexposición menoscabaron gravemente los tratamientos contra el cáncer en Panamá y llevaron a la OPS a examinar de cerca las prácticas de ra- 
dioterapia oncológica en América Latina y el Caribe. Los médicos del ION evaluaron los resultados del tratamiento de 125 pacientes atendidos en ese mismo intervalo de tiempo por los mismos tipos de cáncer sin haber sufrido sobreexposición y encontraron una tasa de recurrencia de cáncer cervicouterino mayor de la esperada. Esto llevó a la OPS a lanzar una iniciativa para la acreditación de los centros de radioterapia oncológica en América Latina y el Caribe, en colaboración con las sociedades profesionales de radioncólogos, físicos médicos y tecnólogos de radioterapia. La Asociación Latinoamericana de Terapia Radiante Oncológica estableció una comisión de acreditación que exigirá que los centros establezcan programas integrales de garantía de la calidad en radioterapia oncológica según los lineamientos internacionales. Asimismo, se recogerán datos estadísticos acerca de los resultados observados en los pacientes tratados para documentar las necesidades de los centros de radioterapia en América Latina y el Caribe, con vistas a definir futuras estrategias en el tratamiento del cáncer.

Palabras clave: Neoplasias pélvicas, radioterapia, traumatismos por radiación, control de calidad, Panamá.

\section{REFERENCES}

1. Borrás C, Barés JP, Rudder D, Amer A, Millán F, Abuchaibe O. Clinical effects in a cohort of cancer patients overexposed during external-beam pelvic radiation therapy. Int J Radiation Oncology Biol Phys. 2004:59(2);538-50.

2. Fletcher GH, ed. Textbook of radiotherapy. 3rd ed. Philadelphia: Lea \& Febiger; 1980.

3. Perez CA, Brady LW, eds. Principles and practice of radiation oncology. 3rd ed. Philadelphia: Lippincott Williams \& Wilkins; 1998.

4. World Health Organization. Radiotherapy in cancer management: a practical manual. London: Chapman \& Hall Medical; 1997.

5. Borrás C. Radiation therapy overexposure. In: Amaral, ECS, Belém Ferreira LMJ, eds. REMPAN 97 proceedings: Seventh Coordination Meeting of World Health Organization Collaborating Centers in Radiation Emergency Medical Preparedness and Assistance Network. Rio de Janeiro: Instituto de Radioproteção e Dosimetria; 1997. Pp. 67-9.

6. International Atomic Energy Agency. Accidental overexposure of radiotherapy patients in San Jose, Costa Rica. Vienna: IAEA; 1998

7. International Commission on Radiation Units and Measurements. Determination of absorbed dose in a patient irradiated by beams of $x$ - or gamma-rays in radiotherapy procedures. Washington, D.C.: ICRU; 1976. (Report 24).

8. International Atomic Energy Agency. Investigation of an accidental overexposure of radiotherapy patients in Panama. Vienna: IAEA; 2001

9. British Journal of Radiology. Central axis depth dose data for use in radiotherapy. London: The British Institute of Radiology; 1996. (The British Journal of Radiology Supplement 25).

10. Young MEJ, Batho HF. Dose tables for linear radium sources calculated by an electronic computer. Brit J Radiol. 1964; 37:38-44.

11. Perez CA, Breaux $\mathrm{S}$, Madoc-Jones $\mathrm{H}_{i}$ Camel HM, Purdy J, Sharma S, et al.
Correlation between dose and tumor recurrence and complications in carcinoma of the uterine cervix: stage I and II-A. Int J Radiat Oncol Biol Phys. 1979;5: 373-82.

12. International Atomic Energy Agency. Lessons learned from accidental exposures in radiotherapy. Vienna: IAEA; 2000. (Safety Reports Series No. 17).

13. United States, Nuclear Regulatory Commission. Code of Federal Regulations, Title 10: Energy, Part 35: medical use of byproduct material. Washington, D.C.: NRC; 1980. (45 FR 31704, 10 CFR 35.41).

14. United States, Nuclear Regulatory Commission. Code of Federal Regulations, Title 10: Energy, Part 35: medical use of byproduct material. Washington, D.C.: NRC; 2002. (67 FR 20370, 10 CFR 35.2).

15. Vatnitsky S, Ortiz Lopez P, Iżewska J, Meghzifene A, Levin V. The radiation overexposure of radiotherapy patients in Panama. Radiother Oncol. 2001;60: 237-8.

16. Thames HD, Hendry JH. Fractionation in radiotherapy. London: Taylor and Francis; 1987.

17. Cox JD, Stetz J, Pajak TF. Toxicity criteria of the Radiation Therapy Oncology Group (RTOG) and the European Organization for Research and Treatment of Cancer (EORTC). Int J Radiat Oncol Biol Phys. 1995;31(5):1341-6.

18. Rubin P, Constine L, Fajardo LF, Philips TL, Wasserman TH. Overview: Late Effects of Normal Tissues (LENT) scoring system. Int J Radiat Oncol Bio Phys. 1995;31(5):1041-2.

19. Pavy JJ, Denekamp J, Letschert J, Littbrand B, Mornex F, Bernier J, et al. Late effects toxicity scoring: the SOMA scale. Int J Radiat Oncol Bio Phys. 1995;31(5): 1043-7.

20. International Journal of Radiation Oncology Biology Physics. LENT SOMA scales for all anatomical sites. Int J Radiat Oncol Biol Phys. 1995;31(5):1049-93.

21. Jung H, Beck-Bornholdt HP, Svoboda V, Alberti W, Herrmann T. Quantification of late complications after radiation therapy. Radiother Oncol. 2001;61:233-46.
22. International Commission on Radiological Protection. Prevention of accidental exposures to patients undergoing radiotherapy. A report of the International Commission on Radiological Protection. Ann ICRP. 2000;30(3):7-70.

23. United Nations Scientific Committee on the Effects of Atomic Radiation. Sources, effects and risks of ionizing radiation. 1988 report to the General Assembly, with annexes. New York: United Nations; 1988.

24. Mettler FA, Landberg $T$, Nénot JC, Medina-Trejos F, Ching R, Garcia I, et al. A 2-year medical follow-up of the radiotherapy accident in Costa Rica. In: Gusev IA, Guskova AK, Mettler FA, eds. Medical management of radiation accidents. Boca Raton: CRC Press; 2001. Pp. 299-311.

25. Cosset JM. ESTRO Breur Gold Medal Award Lecture 2001: irradiation accidents-lessons for oncology? Radiother Oncol. 2002;63:1-10.

26. Zunino S, Rosato O, Lucino S, Jauregui E, Rossi L, Venencia D. Anatomic study of the pelvis in carcinoma of the uterine cervix as related to the box technique. Int J Radiat Oncol Biol Phys. 1999;44: 53-9.

27. Brady LW, Perez CA, Bedwinek JM. Failure patterns in gynecologic cancer. Int J Radiat Oncol Biol Phys. 1986;12: 549-57.

28. Sakurai H, Mitsuhashi N, Takahashi M, Akimoto T, Muramatsu H, Ishikawa H, et al. Analysis of recurrence of squamous cell carcinoma of the uterine cervix after definitive radiation therapy alone: patterns of recurrence, latent periods and prognosis. Int J Radiat Oncol Biol Phys. 2001;50:1136-44.

29. Perez CA, Breaux $S$, Madoc-Jones $H$ Bedwinek JM, Camel HM, Purdy JA, et al. Radiation therapy alone in the treatment of carcinoma of uterine cervix. I. Analysis of tumor recurrence. Cancer. 1983;51:1393-1402.

30. Lanciano R. Optimizing radiation parameters for cervical cancer. Semin Radiat Oncol. 2000;10(1):36-43.

31. Fyles A, Keane TJ, Barton M, Simm J. The effect of treatment duration in the 
local control of cervix cancer. Radiother Oncol. 1992;25(4):273-9.

32. Hendry JH, Bentzen SM, Dale RG, Fowler JF, Wheldon TE, Jones B, et al. A modelled comparison of ways to compensate for missed treatment days in radiotherapy. Clin Oncol (R Coll Radiol). 1996;8(5):297-307.

33. Perez CA, Grigsby PW, Castro Vita H, Lockett MA. Carcinoma of the uterine cervix. I. Impact of prolongation of overall treatment time and timing of brachytherapy on outcome of radiation therapy. Int J Radiat Oncol Biol Phys. 1995; 32:1275-88.

34. Instituto Nacional de Cancerología Ministerio de la Protección Social, Organización Panamericana de la Salud/ Organización Mundial de la Salud. Evaluación de los servicios de radioterapia en Colombia. Santa Fe de Bogotá: Instituto Nacional de Cancerología; 2005.

35. Asociación Latinoamericana de Terapia Radiante Oncológica. ALATRO. Asociación Latinoamericana de Terapia Radiante Oncológica. Available at: http:// www.alatro.org/ [Web site]. Accessed 11 July 2006.

36. World Health Organization. Quality assurance in radiotherapy: a guide prepared following a workshop held at Schloss Reisenburg, Federal Republic of Germany, 3-7 December 1984, and organized jointly by Institute of Radiation Hygiene and World Health Organization. Geneva: WHO; 1988.

37. Hanks G, Svensson G, eds. Quality assurance in radiation therapy: clinical and physical aspects. Proceedings of the First International Symposium on Quality Assessment in Radiation Oncology. New York: Pergamon Press; 1984. (International Journal of Radiation Oncology, Biology, Physics, Volume 10 Supplement 1).

38. Borrás $\mathrm{C}$, ed. Organization, development, quality assurance and radiation protection in radiology services: imaging and radiation therapy. Washington, D.C.: Pan American Health Organization; 1997.

39. Alexander Harris Solicitors. Patients given wrong dose of radiation. Available from: http://www.alexharris.co. uk/page/_Radiotherapy_110.asp [Web site]. Accessed 11 August 2005.
40. Food and Agriculture Organization of the United Nations, International Atomic Energy Agency, International Labour Organisation, Nuclear Agency of the Organisation for Economic Co-operation and Development, Pan American Health Organization, World Health Organization. International basic safety standards for protection against ionizing radiation and for the safety of radiation sources. Vienna: IAEA; 1997. (International Atomic Energy Agency Safety Series 115).

41. European Commission. Council Directive 97/43/Euratom of 30 June 1997 on health protection of individuals against the dangers of ionizing radiation in relation to medical exposure, and repealing Directive 84/466/Euratom. Available from: http://survey.ear-online.org/ national_societies/EU_CouncilDirective. pdf [Web site]. Accessed 13 July 2006.

42. Sociedad Española de Física Médica. El accidente del acelerador lineal en el Hospital Clínico de Zaragoza. Madrid: SEFM; 1991.

43. Borrás C. Medical physicists' roles and responsibilities in accidental medical exposures. In: $\mathrm{Ng} \mathrm{KH}$, Jamal N, Muhammad SN, eds. Proceedings of the 3rd South-East Asian Congress of Medical Physics (SEACOMP) and 4th AsianOceanian Congress of Medical Physics (AOCMP). Kuala Lumpur: Department of Radiology, Faculty of Medicine, University of Malaya; 2004.

44. Costa Rica, Corte Suprema de Justicia. Sala Tercera de la Corte Suprema de Justicia, San José. Exp: 97-000347-0201-PE. Res: 2003-00685. Available from: http:// www.poder-judicial.go.cr/salatercera/ jurisprudencia general/2003/0685-03. doc [Web site]. Accessed 11 August 2005.

45. Diaz C. JM. Cuatro años de prisión para físicos del ION. El Panamá AméricaEPASA. Available from: http://www. elpanamaamerica.com.pa/archive/1118 2004/nation05.shtml [Web site]. Accessed 11 July 2006

46. Gibbs E, Douglas A. Lessons learned from the regulatory control of the accidental exposure of radiotherapy patients occurred in Panama. In: International Atomic Energy Agency. International Conference on National Infrastructures for Radiation Safety: to- wards effective and sustainable systems. Vienna: IAEA, 2004. Pp. 524-7. (IAEA$\mathrm{CN}-107 / 127)$

47. Gage D, McCormick J. "We did nothing wrong." Why software quality matters. Available from: http://www.baseline mag.com/print_article2 / 0,1217, a = 120920,00.asp [Web site]. Accessed 11 August 2005

48. United States, Center for Devices and Radiological Health. FY 03 CDRH annual report. Available from: http:// www.fda.gov/cdrh/annual/fy2003/ fy2003.pdf [Web site]. Accessed $11 \mathrm{Au}-$ gust 2005

49. United States, Nuclear Regulatory Commission, Office of Nuclear Material Safety and Safeguards. Update on radiation therapy overexposures in Panama. Washington, D.C.: NRC; 2001. (Information Notice 2001-08, Supplement 2).

50. FindLaw for Legal Professionals. Opinion. Missouri Court of Appeals Eastern District. Natacha Chandler, et al., Appellants, v. Multidata Systems International Corp., Inc., et al., Respondents. Available from: http://caselaw.lp.find law.com/scripts / getcase.pl?court=mo\& vol=/appeals / 052005/\&invol=ed 84192 2005 [Web site]. Accessed 11 July 2006.

51. Fraass B, Doppke K, Hunt M, Kutcher G, Starkschall G, Stern R, et al. American Association of Physicists in Medicine Radiation Therapy Committee Task Group 53: quality assurance for clinical radiotherapy treatment planning. Med. Phys. 1998:25(10);1773-829.

52. International Atomic Energy Agency. Commissioning and quality assurance of computerized planning systems for radiation treatment of cancer. Available from: http://www-pub.iaea.org/ MTCD/publications/PDF/TRS430 web.pdf [Web site]. Accessed 11 August 2005. (IAEA Technical Report Series No. 430).

Manuscript received 14 December 2004. Revised version accepted for publication 20 April 2006 